\title{
An Up-to-Date Review on Industrially Significant Inhibitors for Corrosion Control of Zinc
}

\author{
Mikitha Pais ${ }^{1} \cdot$ Padmalatha Rao $^{1}{ }^{10}$
}

Received: 3 February 2021 / Revised: 27 May 2021 / Accepted: 13 June 2021 / Published online: 19 June 2021

(c) The Author(s) 2021

\begin{abstract}
Zinc, an important nonferrous metal, is the fourth most used metal in the world. It has innumerable uses in industrial as well as in other segments. The primary utility of zinc is in galvanization and as an anode in the battery. Steel coated with zinc, which is known as galvanized steel, is widely used in industries. Even though zinc protects many metals from undergoing corrosion, by itself, it undergoes corrosion in several acidic, alkaline, and neutral environments. The corrosion behavior of zinc is significant in all industries where it is utilized either directly or indirectly in the form of a sacrificial coating. In-depth analysis of the reported literature indicated that corrosion attenuation of zinc in acidic and alkaline medium was studied by many researchers, and various classes of inhibitors were tried under varying experimental conditions. Most inhibitors can be amalgamated as excellent inhibitors with an inhibition efficiency of $80-90 \%$. Even though this is a subject of intense research, systematic documentation on the same is not available in the literature. This review consolidates research work on corrosion and inhibition studies of zinc and galvanized steel over a period of three decades.
\end{abstract}

Keywords Corrosion $\cdot$ Zinc $\cdot$ Galvanized steel $\cdot$ Corrosion inhibitors $\cdot$ Nanoparticles $\cdot$ Coatings

\section{Introduction}

Corrosion is the unavoidable destruction of metals as well as alloys owing to their interaction with surroundings [1]. Even though ferrous materials are known for undergoing corrosion spontaneously in various acidic, alkaline medium [2], corrosion of nonferrous materials is not new. Numerous reports are available in the literature for corrosion of nonferrous materials such as aluminum and its alloys [3], zinc [4], and other materials $[5,6]$. Zinc is frequently used for coatings other metals, predominantly steel [7]. Zinc will undergo severe corrosion at $\mathrm{pH}$ lower than 6 and above 12. Industrial practices include procedures where metals are being treated with acids during pickling, descaling, etc. Due to these processes, zinc tends to undergo severe corrosion $[8,9]$. The corrosion in marine environments is initiated by interaction between metal surfaces and marine aerosols settled down on it $[10,11]$. Furthermore, zinc is liable to undergo atmospheric corrosion. Proper corrosion prevention helps

Padmalatha Rao

padmalatha.rao@manipal.edu

1 Department of Chemistry, Manipal Institute of Technology, MAHE, Manipal, Karnataka 576104, India to reduce various damages, direct as well as indirect. Thus, material engineers and corrosion scientists intend to lessen the influence of corrosion on all walks of life under multiple situations. Consequently, there would be a decline in economic losses and enhancement of industrial safety, which eventually protects and preserves engineering materials.

Even though researchers have focused on corrosion inhibition studies by adopting various techniques, the utility of corrosion inhibitors has been advocated as the primary tool to retard corrosion rate. Organic inhibitors are heterocyclic compounds containing $\mathrm{O}, \mathrm{N}, \mathrm{S}$, and $\mathrm{P}$ as heteroatoms. These heteroatoms are centers of high electron densities with a lone pair of electrons in them. Through these reactive centers, they quickly form a covalent/coordination bond with metal [12]. Consequently, they tend to form a protecting deposit on the metal surface. It will form a barricade between metal and corrosive which will avoid promoted dissolution of metal and hence material loss [13].

Corrosion inhibitors are practical and flexible means to mitigate corrosion. They are exclusively utilized in innumerable ways in the industrial segments. They are used as the first-line protector in the oil extraction, processing, and chemical industries. These inhibitors minimize the damage of metal, reduce the degree of hydrogen embrittlement, 
protect the metal. They reduce corrosion by either controlling anodic or cathodic or both the reaction. A pictorial illustration for the application of inhibitors in pipelines is depicted in Fig. 1.

In industries, every year, many organic compounds were being synthesized and screened for anti-corrosion performance of different engineering materials in various mediums [14-17]. The other methods employed at the industrial level include coatings, cathodic and anodic protection, in addition to the selection of materials [18-21].

As a part of our research work on the studies of corrosion behavior and corrosion inhibition of nonferrous materials [22-27] under static and dynamic conditions [28], we report herein an up-to-date review on corrosion inhibition strategy for zinc under various corrosive mediums.

\section{Inhibitors for Corrosion Mitigation of Zinc in Acidic Medium}

Zinc is vulnerable to corrosion in an acidic environment. Therefore, pickling [29], descaling [30] are usually done with dilute mineral acids [31]. The accelerated corrosion of zinc results from the predominant cathodic reaction in a highly acidic medium [32]. However, the added inhibitor plays a crucial role by getting adsorbed onto the metal surface, thereby decreasing the speed of hydrogen evolution and protecting the metal surface [7]. Many researchers have comprehensively deliberated the corrosion performance of zinc and inhibition of its corrosion in the acidic environment [33].

$\mathrm{HCl}$ is one of the expansively recommended mineral acids for metal pickling [32, 34-36]. Even though the significant role of the acid here is to remove extraneous materials present on the surface of the material, due to its aggressive nature, even though it is dilute, it dissolves the materials to a considerable extent. Hence, to attenuate the metal dissolution, inhibitors are recurrently added to the acidic solutions.

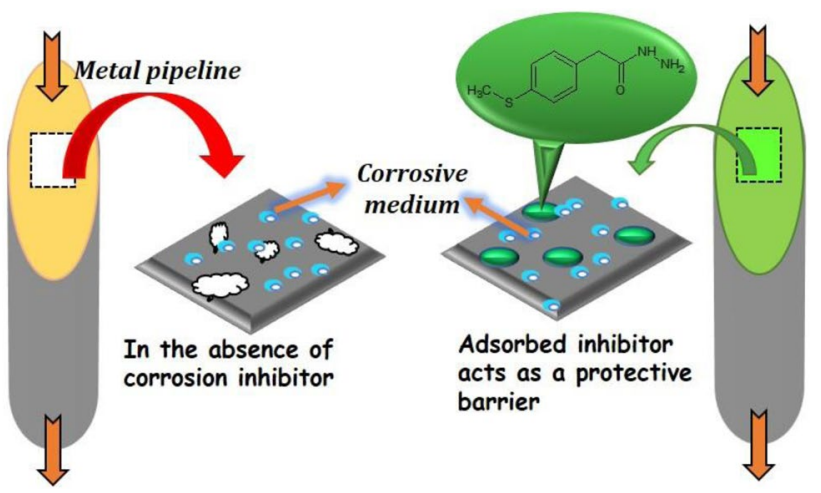

Fig. 1 Application of corrosion inhibitors in pipelines
The inhibitor's efficacy depends on its structure, electrolyte composition, and the charge on the metal surface [37, 38]. Diverse categories of organic compounds have been successfully used as inhibitors.

Many researchers have considered the dissolution of zinc in $\mathrm{HCl}$ employing different classes of chemical inhibitors. Important among them are: ethoxylated fatty alcohols [39], catholyte containing amino-benzotriazole [40] (Fig. S1), aniline [41], 2-[4-(methylthio) phenyl] acetohydrazide and 5-[4(methylthio)benzyl]-4H-1,2,4-triazole-3-thiol [42] (Fig. S2), triethylamine, ethanolamine and triethanolamine [43] (Fig. S3), cetyltrimethyl ammonium bromide (CTAB), bromohexadecyl pyridine and nicotinic acid [9] (Fig. S4), semicarbazide, thiosemicarbazide and diphenylcarbazide [44] (Fig. S5), $\mathrm{C}_{26} \mathrm{H}_{22} \mathrm{~N}_{8} \mathrm{O}_{4}, \mathrm{C}_{26} \mathrm{H}_{22} \mathrm{~N}_{8} \mathrm{O}_{2}, \mathrm{C}_{24} \mathrm{H}_{18} \mathrm{~N}_{8} \mathrm{O}_{2}$, $\mathrm{C}_{24} \mathrm{H}_{16} \mathrm{Cl}_{2} \mathrm{~N}_{8} \mathrm{O}_{2}, \mathrm{C}_{24} \mathrm{H}_{16} \mathrm{~N}_{10} \mathrm{O}_{6}$ [45] (Fig. S6).

Some prominent drugs such as ketosulfone [46] (Fig. S7), streptomycin, spectinomycin, and paromomycin [47] (Fig. S8), Seroquel [48] (Fig. S9), and ziprasidone [49] (Fig. S10) containing active functional groups were useful inhibitors for corrosion of zinc in $\mathrm{HCl}$. Their inhibitive capability is exclusively due to the existence of heterocyclic rings, $\pi$ - and nonbonding electrons.

Sulphuric acid $\left(\mathrm{H}_{2} \mathrm{SO}_{4}\right)$ is used as a cleaner for rust, algae, and scale from condensers and cooling towers [50, 51]. A few studies were carried out using diamine $N, N^{\prime}$-di ( $p$-methoxybenzylidene) and ethylenediamine $N, N^{\prime}$-disalicylidene [52] (Fig. S11), $m$-substituted aniline- $N$-salicylidenes [53] (Fig. S12), ethoxylated fatty acids [54] ethylamines [50] 4-hydroxy phenyl methylidene-2-(1-phenyl ethylidene) hydrazine carbothioamide (4-HPMHC) [55] as inhibitors in sulfuric acid medium.

Limited studies were accomplished on corrosion inhibition of zinc in nitric acid, sulfamic acid, and phosphoric acid. Nitric acid is strongly oxidizing and hence attacks most metals [56]. Even though phosphoric acid is quite mild, it is reported to corrode zinc significantly [57]. Sulfamic acid is a strong acid used as a cleaning agent to remove rust, algae, and hard water scale from cooling towers and condensers [58]. Inhibitors like organic phosphonium and ammonium compounds (Fig. S13) were tried and tested as anticorrosive agents for corrosion of zinc in $1.0 \mathrm{M} \mathrm{H}_{3} \mathrm{PO}_{4}$ [57]. In addition, isomers of toluidines in sulfamic acid and $\mathrm{HNO}_{3}$ $[58,59]$ (Fig. S14) and ethylamine were tried for corrosion hindrance of zinc in $\mathrm{HNO}_{3}$ [60]. The inhibitors mentioned above have shown good inhibition efficiency.

\subsection{Mechanistic Aspects of Acid Corrosion of Zinc}

Metal dissolution in acid is an electrochemical process. At the anode, zinc dissolves, giving corresponding ions [58, 59]. 


\section{$\mathrm{Zn} \rightarrow \mathrm{Zn}^{2+}+2 \mathrm{e}^{-}$}

The reaction taking place in the cathodic region in aerated acidic chloride solution is

$\mathrm{H}^{+}+\mathrm{e}^{-} \rightarrow \mathrm{H}_{\mathrm{ads}}$

$\mathrm{H}_{\mathrm{ads}}+\mathrm{H}_{\mathrm{ads}} \rightarrow \mathrm{H}_{2}$

or

$4 \mathrm{H}^{+}+\mathrm{O}_{2}+4 \mathrm{e}^{-} \rightarrow 2 \mathrm{H}_{2} \mathrm{O}$

The results of various inhibitors reported in the acid medium are tabulated in Table 1.

Careful observation of Table 1 clearly shows that researchers adopted both non-electrochemical and electrochemical methods for corrosion rate measurements. The non-electrochemical method, popularly known as the classical method, mainly involves weight loss techniques [58-60]. On the other hand, potentiodynamic polarization (PDP) measurements and electrochemical impedance spectroscopy (EIS) techniques are extensively applied at laboratory levels. A detailed procedure for these is available in the literature $[49,50,57]$.

The potentiodynamic polarization method suggests the type and behavior of the inhibitor. Based on the shift in corrosion potential $\left(E_{\text {corr }}\right)$ after the inhibition, it is possible to predict whether the inhibitor acts as an anodic inhibitor, cathodic inhibitor, or both. Regarding the literature [61], if the alteration in corrosion potential $\left(E_{\text {corr }}\right)$ is beyond $\pm 85 \mathrm{mV}$, the inhibitor can be treated explicitly either as anodic or cathodic. If not, it can be viewed as a mixed inhibitor. From Table 1, it can be seen that almost $80 \%$ of the inhibitors act as mixed inhibitors. This means added inhibitors are capable of bringing down both anodic and cathodic reactions.

Adsorption isotherm provides information regarding the mode of adsorption of inhibitors onto the metal surface. In addition, it helps evaluate thermodynamic parameters related to adsorption [62]. Langmuir, Flory-Huggins, Frumkin, Bockris-Swinkel, and Temkin were significant isotherms tested and tried to fit experimental data. Linear correlation coefficient $\left(R^{2}\right)$ values, close to unity, were taken to measure best fitment [63] (Fig. S15).

Adsorption of the inhibitor can take place either due to physisorption and chemisorption. Physical adsorption encompasses the electrostatic force of attraction between metal and inhibitor. Chemical adsorption is a consequence of the covalent/coordination bond between metal and inhibitor. The schematic representation of adsorption of inhibitor through physisorption and chemisorption is represented in Fig. 2.
From the above Table 1, it is evident that all the inhibitors showed moderate to good efficiency of about more than $85 \%$, with a few exceptions.

When studies were done under identical conditions [42] among 2-[4-(methylthio) phenyl] acetohydrazide and 5-[4(methylthio)benzyl]-4 h-1,2,4-triazole-3-thiol, the latter turned out to be a very good inhibitor. This is because triazole derivatives are expected to have better adsorption capacity than hydrazide derivatives due to two nitrogen and one sulfur atom.

Inhibition effectiveness of aliphatic amines could be due to the nitrogen atom of the amino group $\left(-\mathrm{NH}_{2}\right)$ [43]. The relatively greater efficiency of ethanolamine is because of the hydroxyl group, which enhances electron concentration on the nitrogen atom, which resulted in better efficacy. To some extent, poor inhibition efficiency is witnessed with triethanolamine. With the increased number of ethanol groups around the nitrogen atom, steric factor arises, which may be responsible for lower inhibition efficiency. The high efficiency of triethylamine may be endorsed to the $-\mathrm{C}_{2} \mathrm{H}_{5}$ group, which enriches the electron charge density of the amino $\left(-\mathrm{NH}_{2}\right)$ group, and liable for increased efficacy.

Corrosion inhibiting capacity of semicarbazide was not as much of thiosemicarbazide and diphenyl carbazide [44]. Diphenylcarbazide demonstrations improved efficiency due to the presence of aryl group and then comes thiosemicarbazide and semicarbazide. The efficiency of the inhibitor depends on molecular size and charge density on the active sites, and it increases with an increase in both [64]. Further, aryl groups are more protective than alkyl groups. So diphenylcarbazide tops the series. Among thiosemicarbazide and semicarbazide, thiosemicarbazide is a better inhibitor due to the presence of sulfur atom, which has more tendency for adsorption than oxygen atom [64].

Among the compounds studied by Fouda et al. [45] compound $A$ with the molecular formula $\mathrm{C}_{26} \mathrm{H}_{22} \mathrm{~N}_{8} \mathrm{O}_{4}$ exhibited maximum efficiency of $91 \%$. This could be attributed to the presence of an electron-donating $\mathrm{p}-\mathrm{OCH}_{3}$ with Hammett constant $\left(\sigma_{\mathrm{pCH} 3}=-0.27\right)$, which is negative. This will upsurge the electron charge density of the atom. However, the least protection efficiency of compound $\mathrm{C}_{24} \mathrm{H}_{16} \mathrm{~N}_{10} \mathrm{O}_{6}$ could be due to the presence of electrons with drawing $\mathrm{p}-\mathrm{NO}_{2}$ groups, with a positive Hammett constant $\left(\sigma_{\mathrm{NO} 2}=+0.78\right)$.

Maximum efficiency of $99 \%$ was observed for diamine $N, N^{\prime}$-di( $p$-methoxybenzylidene) and ethylenediamine $N, N^{\prime}$ disalicylidene [52] $m$-substituted aniline- $N$-salicylidenes [53] owing to the occurrence of electronegative atoms ( $\mathrm{N}$ and $\mathrm{O})$, the unsaturated bonds, and the aromatic ring. 
Table 1 Inhibitors for corrosion mitigation of zinc in acid medium

\begin{tabular}{|c|c|c|c|c|c|c|}
\hline Inhibitor & Method & Medium & Mode of adsorption & Type of inhibitor & Maximum I.E (\%) & Ref \\
\hline $\begin{array}{l}\text { Ethoxylated fatty } \\
\text { alcohols }\end{array}$ & Weight loss, PDP & $0.5 \mathrm{M} \mathrm{HCl}$ & Temkin & Mixed & 88 & [39] \\
\hline $\begin{array}{l}\text { Catholyte containing } \\
\text { aminobenzotriazole }\end{array}$ & Weight loss, PDP & $0.2,0.4,0.6 \mathrm{M} \mathrm{HCl}$ & Temkin & Mixed & 68 & [40] \\
\hline Aniline & Weight loss, PDP & $\begin{array}{c}0.01,0.05,0.10 \\
0.15 \mathrm{M} \mathrm{HCl}\end{array}$ & Langmuir & Mixed & 94 & [41] \\
\hline $\begin{array}{l}\text { 2-[4-(methylthio) phe- } \\
\text { nyl] acetohydrazide } \\
\text { (HYD); 5-[4(methyl- } \\
\text { thio)benzyl]-4 h-1,2,4- } \\
\text { triazole-3-thiol (TRD) }\end{array}$ & Weight loss, PDP, EIS & $0.1 \mathrm{M} \mathrm{HCl}$ & - & Mixed & TRD-95 HYD-71 & [42] \\
\hline $\begin{array}{l}\text { Triethylamine, triethan- } \\
\text { olamine ethanolamine }\end{array}$ & Weight loss, PDP & $\begin{array}{l}0.01,0.025,0.05 \mathrm{M} \\
\quad \mathrm{HCl}\end{array}$ & - & Mixed & $\begin{array}{l}96 \\
66 \\
97\end{array}$ & {$[43]$} \\
\hline $\begin{array}{l}\text { Cetyltrimethyl } \\
\text { ammonium bromide } \\
\text { (CTAB), bromohexa- } \\
\text { decyl pyridine, and } \\
\text { nicotinic acid }\end{array}$ & Weight loss, PDP & $0.5 \mathrm{M} \mathrm{HCl}$ & - & Mixed & - & [9] \\
\hline $\begin{array}{l}\text { Semicarbazide, thiosem- } \\
\text { icarbazide diphenyl- } \\
\text { carbazide }\end{array}$ & $\begin{array}{c}\text { Weight loss, PDP } \\
\text { Thermometric }\end{array}$ & $2 \mathrm{M} \mathrm{HCl}$ & Bockris-Swinkel & Mixed & $\begin{array}{l}30 \\
32 \\
40\end{array}$ & [44] \\
\hline $\begin{array}{l}\mathrm{C}_{26} \mathrm{H}_{22} \mathrm{~N}_{8} \mathrm{O}_{4} \\
\mathrm{C}_{26} \mathrm{H}_{22} \mathrm{~N}_{8} \mathrm{O}_{2} \\
\mathrm{C}_{24} \mathrm{H}_{18} \mathrm{~N}_{8} \mathrm{O}_{2} \\
\mathrm{C}_{24} \mathrm{H}_{16} \mathrm{Cl}_{2} \mathrm{~N}_{8} \mathrm{O}_{2} \\
\mathrm{C}_{24} \mathrm{H}_{16} \mathrm{~N}_{10} \mathrm{O}_{6}\end{array}$ & $\begin{array}{l}\text { EIS, EFM, PDP, } \\
\text { weight loss }\end{array}$ & $0.5 \mathrm{M} \mathrm{HCl}$ & Langmuir & Mixed & $\begin{array}{l}96 \\
94 \\
91 \\
78 \\
68\end{array}$ & {$[45]$} \\
\hline Ketosulfone & PDP, EIS & $0.1 \mathrm{M} \mathrm{HCl}$ & Langmuir & Mixed & 59 & [46] \\
\hline $\begin{array}{l}\text { Streptomycin spectino- } \\
\text { mycin paromomycin }\end{array}$ & PDP, EIS, weight loss & $1 \mathrm{M} \mathrm{HCl}$ & Temkin & Mixed & $\begin{array}{l}91 \\
89 \\
93\end{array}$ & [47] \\
\hline Seroquel & PDP, EIS, weight loss & $0.1 \mathrm{M} \mathrm{HCl}$ & Temkin & Mixed & 82 & [48] \\
\hline Ziprasidone & PDP, EIS, weight loss & $\begin{array}{l}0.1 \mathrm{M} \mathrm{HCl} 0.05 \mathrm{M} \\
\mathrm{H}_{2} \mathrm{SO}_{4}\end{array}$ & - & Mixed & $\begin{array}{l}87 \\
84\end{array}$ & [49] \\
\hline $\begin{array}{l}\text { Ethylenediamine } N, N^{\prime} \text { - } \\
\text { dibenzylidene; ethyl- } \\
\text { enediamine } N, N^{\prime}-\operatorname{di}(p- \\
\text { methoxybenzylidene); } \\
\text { ethylenediamine } \\
N, N^{\prime} \text {-disalicylidene }\end{array}$ & Weight loss & $0.25 \mathrm{M} 0.5 \mathrm{M} \mathrm{H}_{2} \mathrm{SO}_{4}$ & - & Cathodic & 99 & {$[52]$} \\
\hline $\begin{array}{l}m \text {-substituted aniline- } \\
N \text {-salicylidenes }\end{array}$ & $\begin{array}{l}\text { Weight loss, galvano- } \\
\text { static polarisation }\end{array}$ & 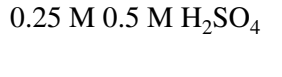 & Langmuir & Cathodic & 99 & {$[53]$} \\
\hline Ethoxylated fatty acids & PDP, weight loss & $\begin{array}{l}1.0 \mathrm{M} \mathrm{HCl} 1.0 \mathrm{M} \\
\mathrm{H}_{2} \mathrm{SO}_{4}\end{array}$ & $\begin{array}{l}\text { Frumkin and Flory- } \\
\text { Huggins }\end{array}$ & Anodic & $\begin{array}{l}80 \\
85\end{array}$ & {$[54]$} \\
\hline Ethylamine & PDP, weight loss, EIS & $0.1,0.3,0.5 \mathrm{M} \mathrm{H}_{2} \mathrm{SO}_{4}$ & Langmuir & Mixed & 92 & {$[50]$} \\
\hline $\begin{array}{l}\text { 4-hydroxy phenyl } \\
\text { methylidene-2-(1- } \\
\text { phenyl ethylidene) } \\
\text { hydrazine carbothio- } \\
\text { amide (4-HPMHC) }\end{array}$ & Weight loss & $\begin{array}{l}0.01,0.02,0.03,0.04 \\
0.05 \mathrm{M} \mathrm{H}_{2} \mathrm{SO}_{4}\end{array}$ & Langmuir & - & 86 & {$[55]$} \\
\hline $\begin{array}{l}\text { Organic phosphonium } \\
\text { and ammonium com- } \\
\text { pounds }\end{array}$ & PDP, EIS & $1 \mathrm{M} \mathrm{H}_{3} \mathrm{PO}_{4}$ & $\begin{array}{l}\text { Frumkin and Lang- } \\
\text { muir }\end{array}$ & Anodic, mixed & 92 & [57] \\
\hline Isomers of toluidines & $\begin{array}{l}\text { Weight loss, galvano- } \\
\text { static polarisation }\end{array}$ & $\begin{array}{l}0.1 \mathrm{M}, 0.5 \mathrm{M}, 1 \mathrm{M} \\
\mathrm{NH}_{2} \mathrm{SO}_{3} \mathrm{H}\end{array}$ & Langmuir & Mixed & 71 & [58] \\
\hline Isomers of toluidines & Weight loss, PDP & $0.15 \mathrm{M}, \mathrm{HNO}_{3}$ & Langmuir & Mixed & 88 & [59] \\
\hline
\end{tabular}


Table 1 (continued)

\begin{tabular}{|c|c|c|c|c|c|}
\hline Inhibitor & Method & Medium & Mode of adsorption & Type of inhibitor & Maximum I.E (\%) Ref \\
\hline $\begin{array}{l}\text { Ethylamine, diethyl- } \\
\text { amine trimethylamine }\end{array}$ & $\begin{array}{l}\text { Weight loss, galvano- } \\
\text { static polarisation }\end{array}$ & $\begin{array}{l}0.01 \mathrm{M}, 0.02 \mathrm{M} \\
0.03 \mathrm{M} \\
\mathrm{HNO}_{3}\end{array}$ & Langmuir & Mixed & $\begin{array}{l}92 \\
91 \\
82\end{array}$ \\
\hline
\end{tabular}

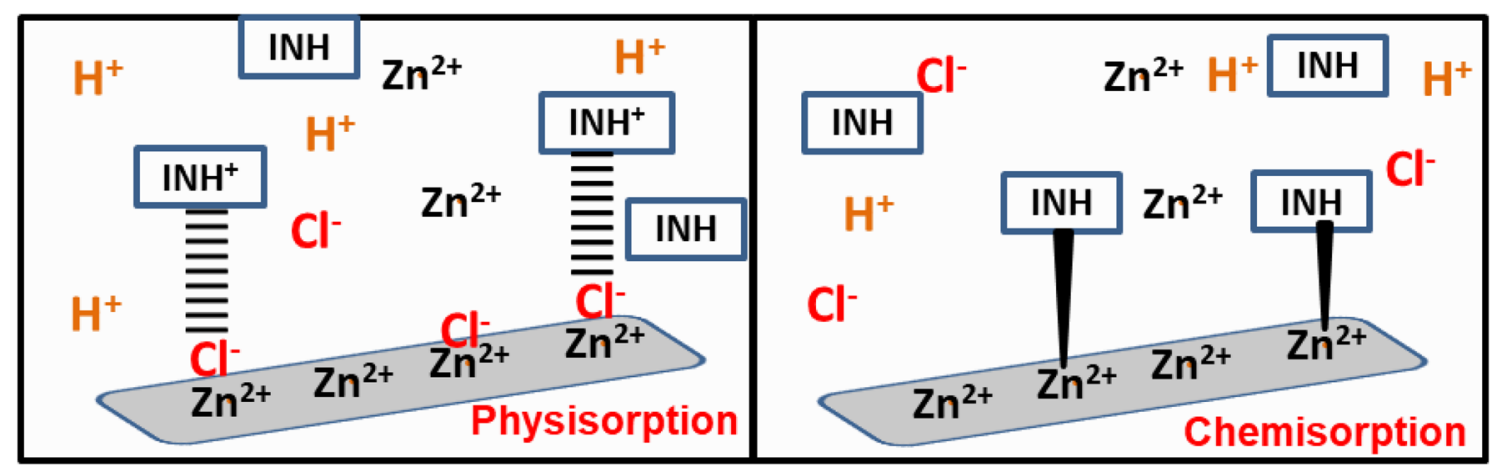

Fig. 2 Depiction of the mechanism of corrosion inhibition through physisorption and chemisorption in $\mathrm{HCl}$ medium

\section{Inhibitors for Corrosion Mitigation of Zinc in Alkaline Medium}

Mercury is expected to attenuate corrosion of zinc in alkaline medium significantly. However, environmental protocols motivate researchers to look for environmentally benign inhibitors. However, recommending a new class of compounds for zinc corrosion in alkaline storage batteries is a severe problem, and it is under investigation. Organic compounds like polyethylene glycol (PEG) and polyoxyethylen alkyl phosphate alky phosphate ester acid (GAFAC RA600) [65], dicarboxylic acid $\left(\mathrm{HCO}_{2}-\mathrm{CH}_{2}-\left(\mathrm{OCH}_{2} \mathrm{CH}_{2}\right)-\mathrm{CH}_{2}-\mathrm{CO}_{2} \mathrm{H}\right)$, modified polyethylene glycol (PEG) [66], surfactants and polyethylene glycols (PEGs PEG200, PEG400) and a surface-active substance of trade name Brij 30 containing ethylene oxide groups as main components $\left.\mathrm{C}_{12} \mathrm{H}_{25} \mathrm{O}-\left[\mathrm{CH}_{2}-\mathrm{CH}_{2}-\mathrm{O}-\right]_{4}-\mathrm{H}\right)$ and ethoxylated polyflouro alcohol (FPEA) [67], dodecyl trimethylammonium bromide (DTAB), tetradecyltrimethylammonium bromide (TTAB), hexadecyltrimethylammonium bromide (HTAB) [68] (Fig. S16) have been studied.

\subsection{Mechanistic Aspects of Alkaline Corrosion of Zinc}

Anodic reaction:

$$
\begin{aligned}
& \mathrm{Zn}+\mathrm{OH}^{-} \rightleftharpoons \mathrm{ZnOH}+\mathrm{e}^{-} \\
& \mathrm{ZnOH}+2 \mathrm{OH}^{-} \rightarrow \mathrm{Zn}(\mathrm{OH})_{3}^{-}+\mathrm{e}^{-}
\end{aligned}
$$

$\mathrm{Zn}(\mathrm{OH})_{3}^{-}+\mathrm{OH}^{-} \rightleftharpoons \mathrm{Zn}(\mathrm{OH})_{4}^{-2}$

Cathodic reaction:

$2 \mathrm{H}_{2} \mathrm{O}+2 \mathrm{e}^{-} \rightleftharpoons \mathrm{H}_{2}+2 \mathrm{OH}^{-}$

Inhibitors used in the alkaline medium are recorded in Table 2

The maximum inhibition efficiency was observed for PEG400 and (FPEA) [67]. From the surface studies, it was seen that PEG400 strongly adsorbed onto the zinc surface, and there was almost no presence of zinc oxide formed. However, the number of inhibitors tried, tested, and reported for their anticorrosive property in alkaline medium is relatively less. This is because zinc undergoes severe corrosion in a highly alkaline medium; electrochemical measurement for the corrosion is very challenging in such a situation.

\section{Inhibitors for Corrosion Mitigation of Zinc in Near-Neutral Medium}

The corrosion in marine environments is determined using chloride media. Therefore, $3.5 \% \mathrm{NaCl}$ solutions are often used to stimulate laboratory conditions and carry out corrosion studies.

Manov et al. [69] explored the corrosion activities of zinc with 2-hydrazono-3-bornan-emethylenedithiol disodium salt (Fig. S17) with chelating groups as inhibitors at pH 6. (mixture of $0.2 \mathrm{M} \mathrm{Na}_{2} \mathrm{SO}_{4}$ and $0.2 \mathrm{M} \mathrm{NaCl}$ ). Inhibitor principally intimidated cathodic reaction. It is due to the chelation 
Table 2 Inhibitors for corrosion mitigation of zinc in alkaline medium

\begin{tabular}{|c|c|c|c|c|}
\hline Inhibitor & Method & Medium & $\begin{array}{l}\text { Maxi- } \\
\text { mum } \\
\text { I.E } \\
(\%)\end{array}$ & $\begin{array}{l}\text { Refer- } \\
\text { ence }\end{array}$ \\
\hline $\begin{array}{l}\text { Polyethylene glycol, polyoxyethylen alkyl phosphate ester } \\
\text { acid }\end{array}$ & Linear polarization potentiodynamic potentiostatic & $8.5 \mathrm{M} \mathrm{KOH}$ & - & {$[65]$} \\
\hline Dicarboxylic acid modified polyethylene glycol & Linear polarization potentiodynamic potentiostatic & $8.5 \mathrm{M} \mathrm{KOH}$ & - & {$[66]$} \\
\hline $\begin{array}{l}\text { PEG200, PEG400, and a surface-active substance Brij } 30 \\
\text { and ethoxylated polyflouro alcohol (FPEA) }\end{array}$ & Potentiodynamic, volumetric, gravimetric & $7 \mathrm{M} \mathrm{KOH}$ & 81 & {$[67]$} \\
\hline DTAB, TTAB, НTAB & $\begin{array}{l}\text { Anodic and cathodic polarization resistance } \\
\text { Potentiodynamic method }\end{array}$ & $2 \mathrm{M} \mathrm{KOH}$ & $\begin{array}{l}66 \\
75 \\
80\end{array}$ & {$[68]$} \\
\hline
\end{tabular}

between zinc and organic molecules, which formed a protective organometallic layer on zinc. Another study was carried out in an aqueous chloride-sulfate medium [70] using Benzaldehyde thiosemicarbazone (BTSC) (Fig. S18) as the inhibitor. Due to highly electronegative nitrogen and sulfur atoms, a strong adherent layer was formed on the metal surface. It was ascertained by surface morphology studies by SEM, EDX, and FT-IR.

Aramaki [71-73] studied zinc's corrosion in $0.5 \mathrm{M} \mathrm{NaCl}$ using various anionic and cationic inhibitors. Maximum efficiency was obtained for using cationic inhibitors [73]. $\mathrm{X}$-ray photoelectron spectra of zinc treated with a solution having $\mathrm{Ce}^{3+}$ shown that dense protective deposit is devoid of chloride ions. Assaf et al. [74] deliberate the pitting corrosion behavior of zinc in $\mathrm{NaCl}, \mathrm{NaBr}$, and $\mathrm{NaI}$. Passivity was developed due to the formation of a protecting barrier of $\mathrm{ZnO}$ at the anodic area. The aggressiveness of halide ions towards the stability of the passive film decreased in the order: $\mathrm{Cl}^{-}>\mathrm{Br}^{-}>\mathrm{I}^{-}$. The corrosion of zinc was enhanced with an increase in the halide ion concentration and temperature. Hinton et al. [75] considered corrosion of zinc and zinc-coated steel in tap water containing small concentrations of cerous chloride. The protecting film was developed by exposing zinc surfaces to cerous chloride solution for a prolonged time or by quenching hot zinc or zinc-coated surfaces into cerous chloride solution. Inhibitors used in the near-neutral medium are listed in Table 3.

Almost a inhibitors showed excellent inhibition efficiency; among them, $\mathrm{Ce}^{3+}$ [73] showed maximum inhibition efficiency. This is because of the direct interaction between hydrated $\mathrm{Ce}^{3+}$ with hydroxide of the solution resulting in the formation of cerium-rich oxide and hydroxide layer.

\section{Inhibitors Patented for Corrosion Mitigation of Zinc}

Charkoudian et al. [76] patented chloride double salt containing mercuric ions and quaternary ions (Fig. 3) as a corrosion inhibitor in a galvanic cell having zinc anode.

Harvey et al. [77] patented corrosion inhibitor for zinccontaining $10 \mathrm{gL}^{-1}$ chromic acid solution in water. Busch et al. [78] patented a corrosion inhibitor for the corrosion control of zinc in open evaporative cooling water circulation systems. The inhibitor was a mixture of various compounds like 2-phosphonobutane-1,2,4-tricarboxylic acid $\left(\mathrm{C}_{7} \mathrm{H}_{11} \mathrm{O}_{9} \mathrm{P}\right)$ (Fig. 4a), phosphono-hydroxyacetic acid $\left(\mathrm{C}_{2} \mathrm{H}_{5} \mathrm{O}_{6} \mathrm{P}\right)$ (Fig. 4b), and sodium diethyldithiocarbamate

Table 3 Inhibitors for corrosion mitigation of zinc in the near-neutral medium

\begin{tabular}{|c|c|c|c|c|}
\hline Inhibitor & Method & Medium & $\begin{array}{l}\text { Maximum } \\
\text { I.E. }(\%)\end{array}$ & Reference \\
\hline $\begin{array}{l}\text { 2-Hydrazono-3-bornanemethylenedithiol diso- } \\
\text { dium salt }\end{array}$ & EIS, polarisation measurements & $0.2 \mathrm{M} \mathrm{Na}_{2} \mathrm{SO}_{4}+0.2 \mathrm{M} \mathrm{NaCl}, \mathrm{pH} 6$ & 90 & {$[69]$} \\
\hline Benzaldehyde thiosemicarbazone (BTSC) & Galvanostatic polarisation & Aqueous chloride-sulfate & 87 & {$[70]$} \\
\hline $\mathrm{Ce}\left(\mathrm{NO}_{3}\right)_{3} \cdot 6 \mathrm{H}_{2} \mathrm{O}$ & PDP & $0.5 \mathrm{M} \mathrm{NaCl}$ & 91 & {$[71]$} \\
\hline $\begin{array}{l}\mathrm{Na}_{2} \mathrm{MoO}_{4} \cdot 2 \mathrm{H}_{2} \mathrm{O}, \mathrm{Na}_{3} \mathrm{PO}_{4} \cdot 12 \mathrm{H}_{2} \mathrm{O} \\
\quad \mathrm{Na}_{2} \mathrm{~B}_{4} \mathrm{O}_{7} \cdot 10 \mathrm{H}_{2} \mathrm{O}\end{array}$ & PDP & $0.5 \mathrm{M} \mathrm{NaCl}$ & 90 & {$[72]$} \\
\hline $\mathrm{Al}^{3+}, \mathrm{La}^{3+}, \mathrm{Ce}^{3+}, \mathrm{Ce}^{4+}$ & PDP & $0.5 \mathrm{M} \mathrm{NaCl}$ & 93 & {$[73]$} \\
\hline- & PDP, Cyclic voltammetry & $\mathrm{NaCl}, \mathrm{NaBr}, \mathrm{NaI}$ & - & [74] \\
\hline $\mathrm{CeCl}_{3} \cdot 7 \mathrm{H}_{2} \mathrm{O}$ & Weight loss, PDP & Tap water or $0.1 \mathrm{M} \mathrm{NaCl}$ & - & {$[75]$} \\
\hline
\end{tabular}




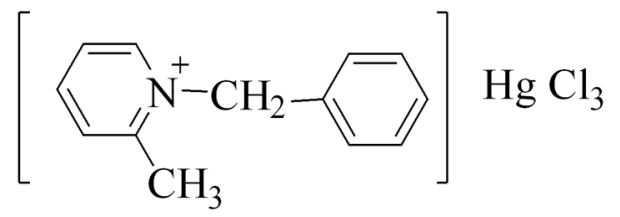

Fig. 3 Structure of chloride double salt containing mercuric ions and quaternary ions

$\left(\mathrm{NaC}_{5} \mathrm{H}_{10} \mathrm{~S}_{2} \mathrm{~N}\right)$ (Fig. $\left.4 \mathrm{c}\right)$. The amalgamation of these compounds was found to constrain the formation of white rust on galvanized steel panels to the extent of $95 \%$ in solution with $\mathrm{pH}$ ranging from 7.5 to 10.0 .

\section{Experimental Techniques}

The majority of literature specified that corrosion and inhibition studies are accomplished employing both classical and electrochemical approaches. Weight loss is one of the most commonly adopted and most reliable methods under classical techniques. It gives highly reproducible results and is still being used by many researchers. However, this method is time-consuming [63]. It will not provide much information regarding the nature of the corrosion inhibition process. Nowadays, researchers prefer fast electrochemical techniques. The potentiodynamic polarization method (PDP), (Fig S19a), which is quite fast, gives a lot of information regarding corrosion current density, corrosion potential, etc. All these electrochemical parameters are beneficial in arriving at the nature and mechanism of corrosion inhibition. The electrochemical impedance spectroscopy (EIS) method helps understand the mechanistic aspects of the corrosion and inhibition process [79] (Fig. S19b). It provides detailed information on the various resistance parameters that play a decisive role in the corrosion and inhibition process. From the carefully done experimental observation, it is possible to prove that inhibition efficiency evaluated from all three methods will agree with one another with less than $2 \%$ deviation.

Careful analysis of published papers related to corrosion inhibition of zinc in various mediums gives the information that surface morphology was studied by SEM (Fig. S20), elemental composition by EDX, and topography was studied by AFM [80]. Surface morphology studies demonstrated the deposition of inhibitors on the surface of the metal, thereby forming a physical barricade between metal and corrosive. The surface has become extraordinarily even after adding the inhibitor. EDX studies were done to understand the elemental composition on the metal surface. In almost all cases, there was a rise in the \% composition of elements, which are accountable for barrier film formation. This reaffirms the adsorption of inhibitors on the surface of the metal. However, this can be further studied and supplemented by spectroscopic techniques and quantum chemical calculations.

\section{Corrosion Inhibition Studies of Galvanized Steel}

Coating iron or steel with zinc is known as galvanization. In galvanized articles, zinc protects the underlying metal by the sacrificial anode method. Zinc, being less noble, will undergo corrosion, thereby protecting the base metal. Hotdip galvanization, thermal spraying, and electrodeposition are primary practices implemented for coating [81]. Galvanized steel pipes have widespread industrial applications. Galvanized steel wires are used in fencing to support wall projections, locking down windows, as a construction material, in telecommunication cables, earth wires, and suspension bridges. Galvanized steel sheets are used in building frames, handrails, street furniture, support beams, nails, nuts and bolts, piping, playground equipment, and automobiles. Galvanized steel bars are used in architectural building features, concrete reinforcement, coastal and marine structures, and transport infrastructures. In industrial sectors, it is used in conveyor castings, chains, supports, storage racks and shelves, electrical conduits, equipment hooks, equipment supports, farm implements, conveyor casing, conveyors, high-speed freezing equipment, cooling towers, condensers [82].

Atmospheric corrosion of galvanized steel structures commences when the $\mathrm{Zn}$ surface becomes damp with rain, mist, or dew [83]. According to the report available in the USA, atmospheric corrosion of zinc is more severe in seawater [84]. Reinforced concrete is an important construction
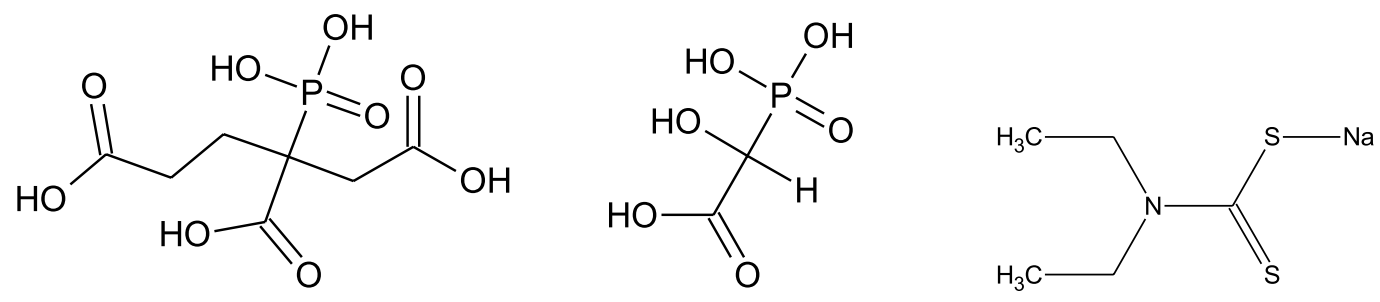

Fig. 4 a 2-phosphonobutane-1,2,4-tricarboxylic acid. b Phosphono-hydroxyacetic acid. c Sodium diethyldithiocarbamate 
material. Hot-dip galvanized reinforcement dramatically diminishes the problem of steel corrosion and concrete spalling. Thus it provides a cost-effective and robust impact on the toughness of the concrete [85].

Even though galvanized steels are comparatively corrosion-resistant, at certain conditions and the medium, they undergo corrosion. An overview of the corrosion pattern seen in galvanized steel is given below.

Al-Saade et al. [86] considered the corrosion of galvanized steel in solutions of $\mathrm{pH} 2-4$ and $8-10$; by adding a minimal concentration $(0.05-1 \mathrm{M})$ sodium chloride at $25-55{ }^{\circ} \mathrm{C}$. In a pure acid medium, corrosion products of zinc were freely soluble in water. In strong alkaline solutions, water-soluble products were formed. This accelerated the corrosion process, not only by destroying the corroded protective layer at galvanized steel surface but also by exposing steel that has to be protected. At high $\mathrm{NaCl}$ concentration, the corrosion rate of zinc declined drastically, at elevated temperatures, specifically in an alkaline medium, because after zinc, the steel that was exposed remained cathodically protected by zinc.

Suzumura et al. [87] studied the corrosion of galvanized steel wires in a humid environment composed of sodium chloride. Corrosion rate increased remarkably with the rise in salt concentration, particularly at elevated temperatures. Further, it was witnessed that this article did not undergo corrosion at a humidity level lower than $60 \%$.

Macias et al. [88] studied the behavior of galvanized corrugated reinforcing bars, which were designed to feign aqueous environments in concrete pores. A white, dusty corrosion product was perceived in the presence of $0.001-1.5 \mathrm{M}$ $\mathrm{KOH}$ and $\mathrm{NaOH}$. In addition, hydrogen evolution was observed $\mathrm{pH}$ greater than the threshold level of $12.8 \pm 0.1$.

Macias et al. [89] studied corrosion of galvanized bars in the $\mathrm{pH}$ range of 11.1-12.6 using calcium hydroxide solutions. Corrosion kinetics were influenced by solution $\mathrm{pH}$ and corrosion products $\mathrm{Ca}\left(\mathrm{Zn}(\mathrm{OH})_{3}\right)_{2} \cdot 2 \mathrm{H}_{2} \mathrm{O}$. Restricted corrosion was detected at $\mathrm{pH}<11.5$.

Kartsonakis et al. [90] explored corrosion resistance of HDG steel panels in sodium chloride solution in the presence of six different inhibitors. In a pH range of 5.8-6.3. $\mathrm{Ce}\left(\mathrm{NO}_{3}\right)_{3}$ exhibited the best corrosion protection, and $\mathrm{Ca}_{3}\left(\mathrm{PO}_{4}\right)_{2}$ had no positive impact.

Wanich et al. [91] used 1,8-diazabicyclo [5,4,0] undec7-ene (DBU) as inhibitor for galvanized steel in $1.0 \mathrm{M} \mathrm{HCl}$, at $30{ }^{\circ} \mathrm{C}$ and $40^{\circ} \mathrm{C}$. Inhibiting efficiency of DBU was up to $88 \%$ at $30^{\circ} \mathrm{C}$.

Zhu et al. [92] studied the corrosion performance of AA 2024-T3, and hot-dip galvanized steel (HDG) in $0.6 \mathrm{M}$ sodium chloride solution. Bis-[3-(triethoxysilyl)propyl] tetrasulfide (bis-sulfur silane), bis-[trimethoxysilylpropyl] amine (bis-amino silane), and their mixture were tried as inhibitors. Hydrophilic bis-amino silane did not exhibit any positive impact on metal dissolution prevention. Hydrophobic bis-sulfur silane accomplished just fine on AA 2024-T3 but futile on HDG. A mixture of bis-sulfur/bis-amino (ratio of 3/1) prominently improved the corrosion tendency of both AA 2024-T3 and HDG.

Coelho et al. [93] deliberated on corrosion opposition of hot-dipped galvanized steel in $0.05 \mathrm{M} \mathrm{NaCl}$. Efficacy of $\mathrm{Na}_{2} \mathrm{MoO}_{4}$ was estimated on HDG substrate, mechanically scratched material. SVET was utilized to examine localized corrosion on scratched HDG samples.

\section{Coating Studies on Galvanized Steel}

As discussed in the previous section, galvanized articles are vulnerable to undergo atmospheric corrosion, and they can be upgraded by smearing. To avoid corrosion and enrich coating adhesions, galvanized steel sheets should be shielded with a film by surface treatment. This is known as coated galvanized steel. This methodology conglomerates benefits of inorganic and organic components. The organic component offers flexibility, diminishes defectiveness, and advances the compatibility with polymer coatings. Simultaneously, the inorganic part is liable for greater adhesion to the metal surface. Moreover, coatings can be carried out at lower temperatures [94].

Acid rain is a mix of $\mathrm{H}_{2} \mathrm{SO}_{4}, \mathrm{HCl}$, and $\mathrm{HNO}_{3}$, which freely react with $\mathrm{Ca}(\mathrm{OH})_{2}$ forming an equivalent amount of hydrated salts. Because of their greater solubility, they infiltrate the inner pores of the concrete. After the evaporation of rainwater, these salts solidify and impart stress on the metallic structure leading to complete damage [95]. According to reports, United States alone spends more than five billion dollars [96] to rectify the destruction of concrete structures triggered by acid rain.

Zin et al. [97] considered corrosion of galvanized steel in artificial acid rain, with a mix of zinc phosphate/molybdate and calcium ion exchange silica. They turned out to have substantial synergetic anti-corrosion influence compared to the pigments used alone.

Barry et al. [98] studied the corrosion activity of pure zinc, 5\% Al-Zn, 55\% Al-Zn film specimens in simulated acid rain. Galvanized steels displayed sacrificial corrosion hindrance for steels. Alloying of zinc and application of inorganic silicon sealer amplified anticorrosive performance.

Pokhmurskyi et al. [99] studied the inhibition activity of pigments containing phosphate and calcium as a substitute for toxic chromate pigments on zinc metal. The corrosion studies were carried out in acid rain. The pigment mix formed phosphate film on metal and delayed the course of corrosion progression. 
Gonzalez et al. [100] smeared epoxy polyamide primer on galvanized steel. Coating thickness was in the range of 100 , 200 , and $500 \mu \mathrm{m}$. Corrosion assessments were accomplished by exposing painted coupons to a $3.0 \% \mathrm{NaCl}$ solution in a horizontal flat cell. The thinnest primer film could not afford sufficient protection for the metal, and metal underwent corrosion. However, the effectiveness of the protection of primer increased with its thickness.

Foremost strategies for corrosion mitigation by coating techniques avoid the electrolyte or air from reaching the metal surface for progressive corrosion reaction. Therefore, most of the work is devoted to replacing harmful chromate coating with safe, non-toxic, environment-friendly replacements, and various such coating formulations are in progress [101].

\section{Coating Studies on Zinc and Galvanised Steel with Nanoparticles}

Anticorrosive properties of the coatings on the galvanized steel could be upgraded by including nanoparticles in the coating. Nanostructured materials maintain exceptional mechanical, electronic, and physicochemical properties because they have a high effective surface area. These properties have urged to prepare coatings of more excellent wear and tear resistance [102, 103].

Montemor et al. [104] studied corrosion of hot-dip galvanized steel pretreated with microparticles of $\mathrm{SiO}_{2}$. Bis1,2-[triethoxysilyl]ethane silane or bis-[triethoxysilylpropyl] tetrasulfide were used for pretreatment. Results showed that the pretreated silane films embodied with silica particles extended maximum corrosion protection.

Montemor et al. [105] explored electrochemical performance of galvanized steel pretreated with bis[triethoxysilylpropyl] tetrasulfide silane (BTESPT) solutions, incorporated with $\mathrm{SiO}_{2}$ or $\mathrm{CeO}_{2}$ nanoparticles activated by cerium ions. Silanes formed a hybrid compact and homogeneous surface film, which became deferment for corrosion initiation. In addition to this, the existence of nanoparticles reinforced the silane films' barrier properties and brought down corrosion action. $\mathrm{CeO}_{2}$ nanoparticles were more prominent than $\mathrm{SiO}_{2}$ nanoparticles.

Motte et al. [106] reported that Silane sol-gel based films could replace customary chromate pre-treatments. Montmorillonite clay was reformed to get $\mathrm{Ce}$ (III) montmorillonite clay (Ce-MMT). Quantity of amalgamated Ce(III) is considered by XRF studies. X-ray diffraction disclosed that the $\mathrm{Ce}(\mathrm{III})$ was situated in interlayer regions. The impact of ionic strength and nature of counterion on the kinetics of $\mathrm{Ce}(\mathrm{III})$ release was explored in $\mathrm{NaCl}$ and $\mathrm{ZnCl}_{2}$ solutions.

Zand and co-workers [107] examined morphological and electrochemical aspects of hot-dip galvanized steel, which was previously treated with 3-glycidoxypropyl trimethoxysilane and bisphenol-A impregnated with cerium ion-activated $\mathrm{CeO}_{2}$ nanoparticles. Results showed the development of a reasonably smooth, nanostructured surface with a small heterogeneity on coating. In addition, the presence of the nanoparticles was reported to reinforce barrier properties of the silane films, reducing corrosion activity.

Neha et al. [108] deliberate on the corrosion diminishing capability of coriander seeds extract by integrating zinc oxide nanoparticles for zinc corrosion in $0.5 \mathrm{M}$ $\mathrm{HCl}$. Examination of polarization records showed that both inhibitors acted as mixed-type. The incorporation of nanoparticles has enhanced the barrier properties of silane coatings due to crack-free films. In addition, nanoparticles enhanced corrosion protection of a sol-gel hybrid coating.

\section{Summary and Conclusions}

In this review article, an account of different chemical inhibitors used to alleviate deterioration of zinc in acid, alkaline, and near neural medium is provided. A detailed study of coating techniques is also given. Most inhibitors can be consolidated as excellent inhibitors with an inhibition efficiency of $80-90 \%$. More inhibitors are reported for acid corrosion than corrosion in alkaline and near-neutral medium. Still, there is more scope to explore the corrosion behavior of zinc in an alkaline medium and introduce innovative class of inhibitors. Some of the inhibitors can be tried for industrial applications. Simultaneously, a few advanced experimental techniques are needed to understand the adsorption tendency of the inhibitor. UV-Vis, FT-IR, AAS, Raman spectroscopy, and X-ray diffraction would provide value-added information to affirm the adsorption of inhibitor onto metal surfaces, which is very much lacking in the reported literature. Furthermore, an insight into computational modelings such as DFT studies, Mulliken charge distribution, and Monte-Carlo Simulation could bring value-added information on the mechanistic aspect of corrosion inhibition in a more realistic way.

Supplementary Information The online version contains supplementary material available at https://doi.org/10.1007/s40735-021-00556-x.

Acknowledgements Ms. Mikitha Pais is grateful to MAHE, Manipal, for awarding the Dr. TMA Pai fellowship. Both authors kindly acknowledge the laboratory facility extended by the Department of Chemistry, MIT MAHE, INDIA.

Funding Open access funding provided by Manipal Academy of Higher Education, Manipal.

\section{Declaration}


Conflict of interest On behalf co-author, the corresponding author claims no conflict of interest.

Open Access This article is licensed under a Creative Commons Attribution 4.0 International License, which permits use, sharing, adaptation, distribution and reproduction in any medium or format, as long as you give appropriate credit to the original author(s) and the source, provide a link to the Creative Commons licence, and indicate if changes were made. The images or other third party material in this article are included in the article's Creative Commons licence, unless indicated otherwise in a credit line to the material. If material is not included in the article's Creative Commons licence and your intended use is not permitted by statutory regulation or exceeds the permitted use, you will need to obtain permission directly from the copyright holder. To view a copy of this licence, visit http://creativecommons.org/licenses/by/4.0/.

\section{References}

1. Raja PB, Ismail M, Ghoreishiamiri S, Mirza J, Ismail MC, Kakooei S, Rahim AA (2016) Reviews on corrosion inhibitors: a short view. Chem Eng Commun 203:1145-1156. https://doi. org/10.1080/00986445.2016.1172485

2. Dwivedi D, Lepkova K, Becker T (2017) Carbon steel corrosion: a review of key surface properties and characterization methods. RSC Adv 7:4580-4610. https://doi.org/10.1039/ C6RA25094G

3. Xhanari K, Finsgar M, Knez Hrncic M, Maver U, Knez Z, Seiti B (2017) Green corrosion inhibitors for aluminium and its alloys: a review. RSC Adv 7:27299-27330. https://doi.org/ 10.1039/c7ra03944a

4. Pais M, Rao P (2019) Biomolecules for corrosion mitigation of zinc: a short review. J Bio- Tribo-Corros 5:1-11. https://doi. org/10.1007/s40735-019-0286-9

5. Fateh A, Aliofkhazraei M, Rezvanian AR (2017) Review of corrosive environments for copper and its corrosion inhibitors. Arab J Chem 13:481-544. https://doi.org/10.1016/j.arabjc. 2017.05.021

6. Ferrando WA (1989) Review of corrosion and corrosion control of magnesium alloys and composites. J Mater Eng 11:299313. https://doi.org/10.1007/BF02834140

7. Abdallah M, Ahmed SA, Altass HM, Zaafarany IA, Salem M, Aly AI, Hussein M, Ahmed SA, Altass HM, Zaafarany IA, Salem M, Aly AI (2018) Competent inhibitor for the corrosion of zinc in hydrochloric acid based on 2,6-bis-[1-(2-phenylhydrazono)ethyl] pyridine. Chem Eng Commun 206:137-148. https://doi.org/10.1080/00986445.2018.1477761

8. Saleh KA, Khalil KS (2014) Corrosion inhibition of zinc in hydrochloric acid solution using Ampicillin. Iraqi J Sci 55:295-303. https://doi.org/10.22401/jnus.10.2.05

9. Sun CX, Chen YM, Xu HW, Huang CS, Zhang M, Wu JY, Chen M, Xue M (2017) Research on the corrosion inhibitors of zinc in hydrochloric acid. Mater Sci Eng 213:012043. https:// doi.org/10.1088/1757-899X/213/1/012043

10. Ivan CC (2017) Recent progress and required developments in atmospheric corrosion of galvanised steel and zinc. Materials (Basel) 10:1288-1300. https://doi.org/10.3390/ma10111288

11. Thomas S, Birbilis N, Venkatraman MS, Cole IS (2012) Corrosion of zinc as a function of $\mathrm{pH}$. Corros NACE Int 68:1-9

12. Peter A, Obot IB, Sharma SK (2015) Use of natural gums as green corrosion inhibitors: an overview. Int J Ind Chem 6:153164. https://doi.org/10.1007/s40090-015-0040-1

13. Yildirim A, Çetin M (2008) Synthesis and evaluation of new long alkyl side chain acetamide, isoxazolidine and isoxazoline derivatives as corrosion inhibitors. Corros Sci 50:155-165. https://doi.org/10.1016/j.corsci.2007.06.015

14. Brycki BE, Kowalczyk IH, Brycki E, Szulc A, Kaczerewska O, Pakiet M, Kowalczyk IH, Szulc A (2018) Organic corrosion inhibitor. In: Aliofkhazraei M (ed) Corrosion inhibitors, principles and recent applications. InTech, Winchester, pp 3-34

15. Fayomi OSI, Anawe PAL, Daniyan A (2018) The impact of drugs as corrosion inhibitors on aluminum alloy in coastal-acidified medium. In: Aliofkhazraei M (ed) Corrosion inhibitors, principles and recent applications. InTech, Winchester, pp 79-94

16. Cheng N, Salas BV, Wiener MS, Martinez JRS (2018) Vapor inhibitors for corrosion protection in humid and saline, natural, and industrial environments. In: Aliofkhazraei M (ed) Corrosion inhibitors, principles and recent applications. InTech, Winchester, pp 165-179

17. Oyekunle DT, Agboola O, Ayeni AO (2019) Corrosion inhibitors as building evidence for mild steel: a review. J Phys Conf Ser 1378:1-23. https://doi.org/10.1088/1742-6596/1378/3/032046

18. Lu WK, Elsenbaumer RL, Wessling B (1995) Corrosion protection of mild steel by coatings containing polyaniline. Synth Met 71:2163-2166. https://doi.org/10.1016/0379-6779(94) 03204-J

19. Briggs T, Eseonu MO (2014) Efficiency of corrosion inhibitors on cathodic protection system. Int J Eng Trends Technol 8:113126. https://doi.org/10.14445/22315381/ijett-v8p222

20. Chigondo M, Chigondo F (2016) Recent natural corrosion inhibitors for mild steel: an overview. J Chem 2016:1-7. https://doi. org/10.1155/2016/6208937

21. Presuel-Moreno F, Jakab MA, Tailleart N, Goldman M, Scully JR (2008) Corrosion-resistant metallic coatings. Mater Today 11:14-23. https://doi.org/10.1016/S1369-7021(08)70203-7

22. Charitha BP, Rao P (2018) Pullulan as a potent green inhibitor for corrosion mitigation of aluminum composite: electrochemical and surface studies. Int J Biol Macromol 112:461-472. https:// doi.org/10.1016/j.ijbiomac.2018.01.218

23. Charitha BP, Rao P (2015) Ecofriendly biopolymer as green inhibitor for corrosion control of 6061-aluminium alloy in hydrochloric acid medium. Int J ChemTech Res 8:330-342

24. Charitha BP, Rao P (2018) Environmentally benign green inhibitor to attenuate acid corrosion of 6061Aluminum-15\%(v) SiC(P) composite. J Ind Eng Chem 58:357-368. https://doi.org/10. 1016/j.jiec.2017.09.049

25. Charitha BP, Rao P (2017) Carbohydrate biopolymer for corrosion control of 6061 Al-alloy and 6061Aluminum-15\%(v) SiC(P) composite-Green approach. Carbohydr Polym 168:337-345. https://doi.org/10.1016/j.carbpol.2017.03.098

26. Charitha BP, Rao P (2017) An ecofriendly approach for corrosion control of $6061 \mathrm{Al}-15 \%$ (v) SiC(P) composite and its base alloy. Chin J Chem Eng 25:363-372. https://doi.org/10.1016/j.cjche. 2016.08.007

27. Prabhu D, Rao P (2013) Corrosion inhibition of 6063 aluminum alloy by Coriandrum sativum L. seed extract in phosphoric acid medium. J Mater Environ Sci 4:732-743

28. Lavanya M, Murthy VR, Rao P (2018) Electrochemical investigation of erosion-corrosion behavior of 6061 aluminum alloy in marine environment. Tribol Ind 40:552-564. https://doi.org/10. 24874/ti.2018.40.04.04

29. Lgaz H, Subrahmanya Bhat K, Salghi R, Shubhalaxmi JS, Algarra M, Hammouti B, Ali IH, Essamri A (2017) Insights into corrosion inhibition behavior of three chalcone derivatives for mild steel in hydrochloric acid solution. J Mol Liq 238:71-83. https://doi.org/10.1016/j.molliq.2017.04.124

30. Lgaz H, Salghi R, Jodeh S (2016) Corrosion inhibition potentiality of some benzimidazole derivatives for mild steel in hydrochloric acid: electrochemical and weight loss studies. 
Int J Corros Scale Inhib 5:347-359. https://doi.org/10.17675/ 2305-6894-2016-5-4-5

31. Lgaz H, Zehra S, Albayati MR, Toumiat K, El Aoufir Y, Chaouiki A, Salghi R, Ali IH, Khan MI, Chung IM, Mohamed SK (2019) Corrosion inhibition of mild steel in $1.0 \mathrm{M} \mathrm{HCl}$ by two hydrazone derivatives. Int J Electrochem Sci 14:6667-6681. https://doi.org/ 10.20964/2019.07.08

32. Shah MD, Panchal VA, Mudaliar GV, Shah NK (2011) Inhibitive effect of salicylidene- $N$ - $N^{\prime}$-dimorpholine towards corrosion of zinc in hydrochloric acid. Anti-Corros Methods Mater 58:125130. https://doi.org/10.1108/00035591111130505

33. Desai MN, Rana SS, Gandhi MH (1973) Corrosion inhibitors for zinc. Anti-Corros Methods Mater 20:3-6. https://doi.org/10. 1108/eb006939

34. Guruprasad AM, Sachin HP, Swetha GA, Prasanna BM (2020) Corrosion inhibition of zinc in $0.1 \mathrm{M}$ hydrochloric acid medium with clotrimazole: experimental, theoretical and quantum studies. Surf Interfaces 19:100478. https://doi.org/10.1016/j.surfin. 2020.100478

35. Amin MA, Abd El-Rehim SS, El-Sherbini EEF, Bayoumi RS (2007) The inhibition of low carbon steel corrosion in hydrochloric acid solutions by succinic acid. Part I. Weight loss, polarization, EIS, PZC, EDX and SEM studies. Electrochim Acta 52:3588-3600. https://doi.org/10.1016/j.electacta.2006.10.019

36. Ostovari A, Hoseinieh SM, Peikari M, Shadizadeh SR, Hashemi SJ (2009) Corrosion inhibition of mild steel in $1 \mathrm{M} \mathrm{HCl}$ solution by henna extract: a comparative study of the inhibition by henna and its constituents (Lawsone, Gallic acid, $\alpha$-d-Glucose and Tannic acid). Corros Sci 51:1935-1949. https://doi.org/10.1016/j. corsci.2009.05.024

37. Moretti G, Guidi F, Grion G (2004) Tryptamine as a green iron corrosion inhibitor in $0.5 \mathrm{M}$ deaerated sulphuric acid. Corros Sci 46:387-403. https://doi.org/10.1016/S0010-938X(03)00150-1

38. Adindu CB, Oguzie EE, Chidiebere MA (2016) Corrosion inhibition and adsorption behavior of extract of funtumia elastica on mild steel in acidic solution. Int Lett Chem Phys Astron 66:119132. https://doi.org/10.18052/www.scipress.com/ilcpa.66.119

39. Abdallah M (2003) Ethoxylated fatty alcohols as corrosion inhibitors for dissolution of zinc in hydrochloric acid. Corros Sci 45:2705-2716. https://doi.org/10.1016/S0010-938X(03)00107-0

40. Sachin HP, Praveen BM, Abd Hamid SB (2013) Corrosion inhibition of zinc by a new inhibitor in hydrochloric acid medium. Res J Chem Sci 3:82-89

41. Vashi RT, Desai K (2013) Aniline as corrosion inhibitor for zinc in hydrochloric acid. Chem Sci Trans 2:670-676. https://doi.org/ $10.7598 / \mathrm{cst} 2013.423$

42. Shylesha BS, Venkatesha TV, Praveen BM (2011) New electroactive compounds as corrosion inhibitors for zinc in acidic medium. Adv Appl Sci Res 2:333-341

43. Mahida MB, Chaudhari HG (2012) Aliphatic amines as corrosion inhibitors for zinc in hydrochloric acid. Der Pharma Chem 4:2305-2312

44. Fouda AS, Madkour LH, El-Shafei AA, El MSAA (1995) Corrosion inhibitors for zinc in $2 \mathrm{M} \mathrm{HCl}$ solution. Bull Korean Chem Soc 16:454-458

45. Fouda AS, Rashwan S, Emam A, El-Morsy FE (2018) Corrosion inhibition of zinc in acid medium using some novel organic compounds. Int J Electrochem Sci 13:3719-3744. https://doi.org/ $10.20964 / 2018.04 .23$

46. Hebbar N, Praveen BM, Prasanna BM, Venkatesha TV (2015) Corrosion inhibition behaviour of ketosulfone for zinc in acidic medium. J Fundam Appl Sci 7:271-289

47. Abdallah M, Zaafarany IA, Al Jahdaly BA (2016) Corrosion inhibition of zinc in hydrochloric acid using some antibiotic drugs. J Mater Environ Sci 7:1107-1118
48. Guruprasad AM, Sachin HP, Swetha GA, Prasanna BM (2019) Adsorption and inhibitive properties of seroquel drug for the corrosion of zinc in $0.1 \mathrm{M}$ hydrochloric acid solution. Int $\mathrm{J}$ Ind Chem 10:17-30. https://doi.org/10.1007/s40090-018-0168-x

49. Shylesha BS, Venkatesha TV, Praveen BM (2011) Ziprasidone as a corrosion inhibitor for zinc in different acid medium. J Chem Pharm Res 3:501-507

50. Zele S, Rt V (2016) Inhibition of corrosion of zinc in sulphuric acid by ethylamines. Int $\mathrm{J}$ Chem Stud 4:31-38

51. Jawad QA, Zinad DS, Salim RD, Al-Amiery AA, Gaaz TS, Takriff MS, Kadhum AAH (2019) Synthesis, characterization, and corrosion inhibition potential of novel thiosemicarbazone on mild steel in sulfuric acid environment. Coatings 9:1-15. https:// doi.org/10.3390/coatings9110729

52. Agrawal YK, Talati JD, Shah MD, Desai MN, Shah NK (2004) Schiff bases of ethylenediamine as corrosion inhibitors of zinc in sulphuric acid. Corros Sci 46:633-651. https://doi.org/10.1016/ S0010-938X(03)00174-4

53. Talati JD, Desai MN, Shah NK (2005) Meta-substituted aniline$\mathrm{N}$-salicylidenes as corrosion inhibitors of zinc in sulphuric acid. Mater Chem Phys 93:54-64. https://doi.org/10.1016/j.match emphys.2005.02.004

54. El-Sherbini EEF, Wahaab SMA, Deyab M (2005) Ethoxylated fatty acids as inhibitors for the corrosion of zinc in acid media. Mater Chem Phys 89:183-191. https://doi.org/10.1016/j.match emphys.2003.09.055

55. Fk O, Ogueji C, Nm M (2016) Inhibition of corrosion of zinc in $\mathrm{H}_{2} \mathrm{SO}_{4}$ medium by the Schiff base, 4-hydroxy phenyl methylidene-2-(1-phenyl ethylidene) hydrazine carbothioamide (4-HPMHC). Der Chem Sin 7:13-20

56. Whillock GOH, Worthington SE, Abdullahi AA (2017) Corrosion in nitric acid. In: Hashmi S (ed) Reference module in materials science and materials engineering. Elsevier, Oxford, pp 1-22

57. Morad MS (1999) Inhibition of phosphoric acid corrosion of zinc by organic onium compounds and their adsorption characteristics. J Appl Electrochem 29:619-626. https://doi.org/10.1023/A: 1026445521937

58. Vashi RT, Champaneri VA (1997) Toluidines as corrosion inhibitors for zinc in sulphamic acid. Indian J Chem Technol $4: 180-184$

59. Vashi R, Desai S, Desai PS (2008) Toluidines as corrosion inhibitors for zinc in nitric acid. Ultra Chem 4:27-34

60. Vashi RT, Desai SA, Champaneri VA, Patel RN (2004) Ethanolamines as corrosion inhibitors for zinc in nitric acid. Bull Electrochem 20:187-192

61. Li WH, He Q, Zhang ST, Pei CL, Hou BR (2008) Some new triazole derivatives as inhibitors for mild steel corrosion in acidic medium. J Appl Electrochem 38:289-295. https://doi.org/10. 1007/s10800-007-9437-7

62. Salarvand Z, Amirnasr M, Talebian M, Raeissi K, Meghdadi S (2017) Enhanced corrosion resistance of mild steel in $1 \mathrm{M} \mathrm{HCl}$ solution by trace amount of 2-phenyl-benzothiazole derivatives: experimental, quantum chemical calculations and molecular dynamics (MD) simulation studies. Corros Sci 114:133-145. https://doi.org/10.1016/j.corsci.2016.11.002

63. Pais M, Rao P (2020) Maltodextrin for corrosion mitigation of zinc in sulfamic acid: electrochemical, surface and spectroscopic studies. Int J Biol Macromol 145:575-585. https://doi.org/10. 1016/j.ijbiomac.2019.12.197

64. Sanyal B (1981) Organic compounds as corrosion inhibitors in different environments: a review. Prog Org Coat 9:165-236

65. Ein-Eli Y, Auinat M, Starosvetsky D (2003) Electrochemical and surface studies of zinc in alkaline solutions containing organic corrosion inhibitors. J Power Sources 114:330-337

66. Auinat M, Ein-eli Y (2005) Enhanced inhibition of zinc corrosion in alkaline solutions containing carboxylic acid modified PEG. 
J Electrochem Soc 152:1158-1164. https://doi.org/10.1149/1. 1900963

67. Dobryszycki J, Biallozor S (2001) On some organic inhibitors of zinc corrosion in alkaline media. Corros Sci 43:1309-1319

68. Pruna A, Brânzoi V, Brânzoi F (2007) Corrosion inhibition of zinc in KOH solutions. Adv Mater Res 23:233-236. https://doi. org/10.4028/www.scientific.net/AMR.23.233

69. Manov S, Lamazouère AM, Ariès L (2000) Electrochemical study of the corrosion behaviour of zinc treated with a new organic chelating inhibitor. Corros Sci 42:1235-1248. https:// doi.org/10.1016/S0010-938X(99)00132-8

70. Rajappa SK, Venkatesha TV, Praveen BM (2008) Chemical treatment of zinc surface and its corrosion inhibition studies. Bull Mater Sci 31:37-41

71. Aramaki K (2001) Treatment of zinc surface with cerium (III) nitrate to prevent zinc corrosion in aerated $0.5 \mathrm{M} \mathrm{NaCl}$. Corros Sci 43:2201-2215

72. Aramaki K (2001) The inhibition effects of chromate-free, anion inhibitors on corrosion of zinc in aerated $0.5 \mathrm{M} \mathrm{NaCl}$. Corros Sci 43:591-604

73. Aramaki K (2001) The inhibition effects of cation inhibitors on corrosion of zinc in aerated $0.5 \mathrm{M} \mathrm{NaCl}$. Corros Sci 43:1573-1588

74. Assaf FH, El-rehiem SSA, Zaky AM (1999) Pitting corrosion of zinc in neutral halide solutions. Mater Chem Phys 58:58-63

75. Hinton BRW, Wilson L (1989) The corrosion inhibition of zinc with cerous chloride. Corros Sci 29:967-985

76. Charkoudian JC, Hoffman A (1978) Battery electrolyte corrosion inhibitor. United States Patent, Patent number 4,112,205

77. Harvey GJ, Cameron DI (1971) Composition and process for inhibiting corrosion of zinc surfaces. United States Patent Office, Patent number 3,553,034

78. Busch BD, M Oldsberg (1995) Galvanized metal corrosion inhibitor. United States Patent, Patent number 5,407,597

79. Pais M, Rao P (2020) Electrochemical approaches for material conservation: experimental and theoretical insights using a biopolymer. J Bio- Tribo-Corros 6:1-13. https://doi.org/10.1007/ s40735-020-00412-4

80. Pais M, Rao P (2020) Electrochemical, spectroscopic and theoretical studies for acid corrosion of zinc using glycogen. Chem Pap 75:1387-1399. https://doi.org/10.1007/s11696-020-01391-z

81. Hosking NC, Strom MA, Shipway PH, Rudd CD (2007) Corrosion resistance of zinc-magnesium coated steel. Corros Sci 49:3669-3695. https://doi.org/10.1016/j.corsci.2007.03.032

82. Haque MM, Limon SA, Moniruzzaman M, Bepari MMA (2014) Corrosion comparison of galvanized steel and aluminum in aqueous environments. Int J Automot Mech Eng 9:1758-1767. https:// doi.org/10.15282/ijame.9.2013.24.0146

83. Syed S (2014) Atmospheric corrosion of materials. Emir J Eng Res 11:1-24

84. Moniruzzaman M, Bepari M (2014) Corrosion of galvanized steel and copper in aqueous environments. J Mech Eng 43:61-67. https://doi.org/10.15282/ijame.9.2013.24.0146

85. Hegyi A, Dico C, Constantinescu H, Baera C (2017) Influence of hot-dip galvanizing of reinforcement on the kinetics and thermodynamics of corrosion process in concrete. In: Proceedings of the 10 th international conference interdisciplinary in engineering, $\mathrm{pp}$ 226-233

86. Al-saade K, Abas HA (2013) Corrosion study of galvanized steel in salty acidic and basic solutions corrosion study of galvanized steel in salty acidic and basic solutions. Dirasat Pure Sci 39:108-116

87. Suzumura K, Nakamura S, Asce M (2004) Environmental factors affecting corrosion of galvanized steel wires. J Mater Civ Eng 16:1-7. https://doi.org/10.1061/(ASCE)0899-1561(2004)16:1(1)
88. Macais A, Andrade C (1987) Corrosion of galvanized steel reinforcements in alkaline solutions. Br Corros J 22:113-118

89. Macias A, Andrade C (1987) Corrosion of galvanized steel in dilute $\mathrm{Ca}(\mathrm{OH})_{2}$ solutions $(\mathrm{pH} 11.1-12.6)$. Br Corros J 22:162-171

90. Kartsonakis IA, Stanciu SG, Matei AA, Hristu R, Karantonis A, Charitidis CA (2016) A comparative study of corrosion inhibitors on hot-dip galvanized steel. Corros Sci 112:289-307. https://doi. org/10.1016/j.corsci.2016.07.030

91. Limwanich W, Meepowpan P, Punyodom W, Kungwan N (2018) Corrosion inhibition of galvanized steel in hydrochloric acid solution using 1,8-diazabicyclo[5.4.0] undec-7-ene as new organic inhibitor. Burapha Sci J 23:594-607

92. Zhu D, Van OWJ (2004) Enhanced corrosion resistance of AA 2024-T3 and hot-dip galvanized steel using a mixture of bis[triethoxysilylpropyl] tetrasulfide and bis-[trimethoxysilylpropyl] amine. Electrochim Acta 49:1113-1125. https://doi.org/10. 1016/j.electacta.2003.10.023

93. Coelho LB, Fava EB, Kooijman AM, Gonzalez-Garcia Y, Olivier MG (2020) Molybdate as corrosion inhibitor for hot dip galvanised steel scribed to the substrate: a study based on global and localised electrochemical approaches. Corros Sci 175:108893. https://doi.org/10.1016/j.corsci.2020.108893

94. Bao Y, Ren L, Yu Z, Jiang Y, Yang K (2018) An experimental study on contact resistance of coated galvanized steel sheet. Weld World 62:511-516. https://doi.org/10.1007/s40194-018-0583-9

95. Webster RP, Kukacka LE (1986) Effects of acid deposition on portland cement concrete. In: Materials degradation caused by acid rain. ACS Symposium Series, vol 16, pp 239-249

96. Zhang Y, Fan Y, Li H (2012) Influence of simulated acid rain corrosion on the uniaxial tensile mechanical properties of concrete. Int J Corros 2012:1-7. https://doi.org/10.1155/2012/172394

97. Zin IM, Lyon SB (2003) Corrosion control of galvanized steel using a phosphate/calcium ion inhibitor mixture. Corros Sci 45:777-788

98. Barry DM, McGrath P, Kanematsu H, Oki T (2003) Corrosion resistance for some galvanized steels under an extreme acid rain environment. In: Proceedings of the 13th Asian-Pacific corrosion control conference Osaka University, pp 16-21

99. Pokhmurskyi VI, Zin IM, Lyon SB (2004) Inhibition of corrosion by a mixture of nonchromate pigments in organic coatings on galvanized steel. Mater Sci 40:383-390

100. Gonzalez S, Gil MA, Hernandez JO, Fox V, Souto RM (2001) Resistance to corrosion of galvanized steel covered with an epoxy-polyamide primer coating. Prog Org Coat 41:167-170

101. Hernandez-alvarado LA, Hernandez LS, Rodriguez-reyna SL (2012) Evaluation of corrosion behavior of galvanized steel treated with conventional conversion coatings and a chromatefree organic inhibitor. Int J Corros 2012:1-8. https://doi.org/10. $1155 / 2012 / 368130$

102. Easwaramoorthi, Suba Kannaiyan, Gopa A (2016) Corrosion inhibition using nanomaterials: an overview. In: Proceedings of the national conference on recent trends in applied chemistry, pp 167-170

103. Pokorny P, Tej P, Szelag P (2016) Chromate conversion coatings and their current application. Metalurgija 55:253-256

104. Montemor MF, Cabral AM, Zheludkevich ML, Ferreira MGS (2006) The corrosion resistance of hot dip galvanized steel pretreated with Bis-functional silanes modified with microsilica. Surf Coat Technol 200:2875-2885. https://doi.org/10.1016/j. surfcoat.2004.11.012

105. Montemor MF, Ferreira MGS (2007) Cerium salt activated nanoparticles as fillers for silane films: evaluation of the corrosion inhibition performance on galvanised steel substrates. Electrochim Acta 52:6976-6987. https://doi.org/10.1016/j.electacta. 2007.05.022 
106. Motte C, Poelman M, Roobroeck A, Fedel M, Deflorian F, Olivier M (2012) Progress in organic coatings improvement of corrosion protection offered to galvanized steel by incorporation of lanthanide modified nanoclays in silane layer. Prog Org Coat 74:326-333. https://doi.org/10.1016/j.porgcoat.2011.12.001

107. Zand RZ, Verbeken K, Adriaens A (2013) Evaluation of the corrosion inhibition performance of silane coatings filled with cerium salt-activated nanoparticles on. Int J Electrochem Sci 8:4924-4940
108. Parekh N, Ladha D, Wadhwani P, Madhup M (2015) Comparative study of natural inhibitor and Np-natural inhibitor for the corrosion protection of zinc in $\mathrm{HCl}$. Nano Vis 5:295-304

Publisher's Note Springer Nature remains neutral with regard to jurisdictional claims in published maps and institutional affiliations. 